УДК 598.33:591.43(571.5)

DOI: $10.18101 / 2542-0623-2019-1-28-54$

\title{
ДИНАМИКА ФАУНЫ КУЛИКОВ КОТЛОВИНЫ ОЗЕРА БАЙКАЛ И ЕЕ СВЯЗЬ С СОВРЕМЕННЫМИ ИЗМЕНЕНИЯМИ КЛИМАТА (КОНЕЦ XVIII — НАЧАЛО ХХI в.)
}

\section{Ю. И. Мельников}

\author{
(C) Мельников Юрий Иванович \\ кандидат биологических наук, \\ Байкальский музей Иркутского научного центра \\ Россия, 664520, Иркутская обл., \\ пос. Листвянка, ул. Академическая, 1 \\ E-mail: yumel48@mail.ru
}

Для цитирования:

Мельников Ю. И. Динамика фауны куликов котловины озера Байкал и ее связь с современными изменениями климата (конец XVIII - начало XXI в.) // Природа Внутренней Азии. Nature of Inner Asia. 2019. № 1(10). С. 28-54.

В работе рассматривается динамика фауны куликов котловины оз. Байкал в зависимости от современных изменений климата (потепление) за длительный период наблюдений (конец XVIII - начало XXI в.). До середины XX в. в Восточной Сибири развивался влажно-холодный период многовекового цикла климата продолжительностью около 2000 лет, относимый к позднеледниковью [Мухина и др., 1965; Леви и др., 2017]. В связи с этим видовой состав куликов в это время был бедным - 45 видов, хотя некоторые из них достигали высокого обилия. Со второй половины XX в. и началом выраженного потепления климата видовой состав куликов в котловине озера Байкал значительно увеличивается (с 45 до 57 видов, всего в Восточной Сибири насчитывается 63 вида). Резкое увеличение видового состава и численности птиц этой группы является следствием выселения к северу ряда типично южных видов куликов. Доказано, что массовые выселения к северу птиц данной группы инициируются крупными, часто катастрофическими засухами в Центральной Азии, сопровождающимися длительными маловодными периодами [Мельников, 2002; 2004]. В первую очередь выселяются птицы влажных и заболоченных лугов, площадь которых в результате сильного иссушения резко сокращается. В связи с этим начало второй половины XX в. отличалось массовыми выселениями лугово-болотных видов куликов, проникшими до Центральноякутской низменности (чибис, поручейник, большой улит, фифи). На втором этапе выселений (конец XX в.), обусловленном сильным обсыханием влажных лугов юга Восточной Сибири, наблюдались сдвиги оптимумов ареалов далеко к северу - на 500 км и более у наиболее массовых видов куликов этой группы - бекас, азиатский бекас, лесной дупель, турухтан. Именно в это время резко сокращается обилие наиболее многочисленных видов куликов, типичных для влажно-холодного периода климата позднеледниковья (XIX - первая половина XX в.). Южные границы их ареалов остались практически неизменными, но плотность населения птиц сократилась в два-три и более раз. У некоторых видов (большой улит, фифи) на местах прежнего высокого обилия сейчас регистрируются только отдельные гнездовые пары. Третья волна выселений, пришедшаяся на начало XXI в., включает пустынные, степные и высокогорные виды. Из наиболее широко распространенных видов предыдущего 
Ю. И. Мельников. Динамика фауны куликов котловины озера Байкал и ее связь с современными изменениями климата (конец XVIII — начало XXI в.)

периода, покидающих даже север Восточной Сибири, необходимо отметить черныша. Увеличение видового состава происходит преимущественно за счет залетных и единично гнездящихся южных видов куликов, северные границы ареалов которых ранее находились близ границ России. Необходимо отметить, что речь идет о группе птиц, осваивающих исключительно водно-болотные экосистемы, являющиеся интразональными местообитаниями, встречающимися во всех природных зонах и горных поясах, что облегчает широкие перемещения таких птиц.

Ключевые слова: озеро Байкал, климат, фауна куликов, видовой состав, численность, динамика ареалов.

\section{Введение}

Фауна куликов Восточной Сибири изучалась достаточно долго, ее видовой состав выявлен практически полностью [Дыбовский, Годлевский, 1870; Тачановский, 1877; Туров, 1923; Воробьев, 1927; Третьяков, 1934; Гусев, 1960; Гагина, 1961; 1974; Скрябин, 1967; Попов, Матвеев, 2006; Доржиев, 2011; Мельников, 2011в; Рябицев, 2014; Georgi, 1775; Maak, 1859; Radde, 1863; Stegmann, 1929; 1936]. Однако видовой состав куликов озера Байкал как самостоятельного зоогеографического региона долгое время никем специально не рассматривался. Такая попытка впервые сделана в середине прошедшего столетия, авторы данной работы достаточно подробно рассмотрели их фауну на Байкале [Толчин и др., 1977]. Несколько позднее к данному вопросу вернулись и другие исследователи региона [Гагина, 1988; Болд и др., 1991; Фефелов и др., 2001; Попов, 2004; Мельников, 2010; Fefelov, Tupitsyn, 2004; Mlikovsky, 2009]. К этому времени уже четко просматривалась общая тенденция к потеплению климата и появлению новых видов, а также к значительному изменению численности многих птиц данной группы. Кроме того, эти авторы рассматривали фауну птиц озера Байкал и его бассейна, включающего значительную часть Восточной Сибири, а нередко и Китая с Монголией. Поэтому приведенные в них списки птиц не отражали состава фауны, включая и куликов, конкретно на данном озере.

В современный период имеется только одна поверхностная работа, в которой специально рассматривается фауна куликов Байкала [Преловский, 2011], и одна детальная статья по водоплавающим и околоводным птицам, однако не учитывающая многие специфические вопросы их статуса и распределения в разные временные периоды [Mlikovsky, 2009]. В более поздних работах анализируется весь состав фауны птиц котловины оз. Байкал, разумеется, включая и куликов [Мельников, 2016а; Мельников, Гагина-Скалон, 2016]. В то же время расположение этого громадного озера на пересечении нескольких миграционных потоков птиц Юго-Восточной и Северной Азии требует более тщательного изучения и анализа данной проблемы. В связи с этим в представленной работе нами проведен специальный анализ динамики фауны куликов озера Байкал, а временной интервал, на протяжении которого рассматривается проблема, охватывает период с конца XVIII по начало XXI в.

\section{Район работ, материал и методика}

Озеро Байкал - один из наиболее крупных пресноводных водоемов континентальной части Северной Азии (длина 635 км, ширина от 25 до 79,5 км, пло-

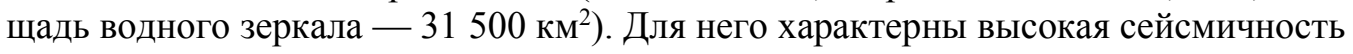


(отдельные землетрясения в 10-11 баллов), сильные ветры, иногда достигающие мощности ураганов $(40-50 \mathrm{~m} / \mathrm{c})$ и достаточно жесткий континентальный климат. С юга на север озера он становится более суровым - коэффициент его жесткости (по Ценкеру) увеличивается с 62 до 64. В связи с огромной массой воды Байкал замерзает очень поздно и постепенно - с севера на юг. Наиболее глубоководные районы, расположенные на юге озера, покрываются льдом только к середине зимы - 11-14 января, а в настоящее время и значительно позже (первая пятидневка февраля). Сроки ледостава по годам различаются на 40 и более дней. Вскрытие ледового покрова на юге озера начинается 25-30 апреля, а в северной его части только в середине июня (9-14 июня). Хорошо прослеживается запаздывание почти на месяц сроков наступления сезонов года в прибрежных районах оз. Байкал [Байкал... 1993].

Горное обрамление озера, обрывистые скалистые берега и очень узкая полоса прибрежных мелководий резко сокращают площадь стаций, пригодных для обитания куликов. Основная часть озера (93,0\% поверхности) имеет глубину более 10 м и не пригодна для обитания околоводных и водоплавающих птиц. Они используют только мелководные участки дельт и устьев рек, впадающих в Байкал, а также песчаные косы, формирующиеся по их кромке, и имеющие разные местные названия (дельта р. Селенги (карга), устья р. Верхней Ангары и Кичеры (ярки), устье р. Баргузин) и значительно более мелкие притоки (р. Голоустная, Бугульдейка, Сарма и др.). Здесь имеются стации, используемые всеми видами куликов, но более обычными являются местообитания, характерные для луговоболотных видов, хотя большие площади песчаных пляжей и обсохших после падения уровня воды иловых отмелей обеспечивают необходимые условия и для остальных птиц этой группы (зуйки, камнешарка, песочники и др.) [Мельников, 2013]. Поэтому кулики чаще всего формируют крупные послегнездовые концентрации и миграционные скопления именно на таких участках. Особенно это характерно для периодов их массовых миграций как весной, так и осенью.

Анализ фауны куликов проведен с учетом деления оз. Байкал на климатические округи: Южно-Байкальский, Средне-Байкальский и Северо-Байкальский. Характер распределения птиц, их статус и видовой состав описываются за два периода наблюдений: первый - с конца XVIII по середину XX в. (1950 г. включительно); второй - со второй половины XX по начало XXI в. (с 1951 г.) [Мельников, 2016а; Мельников, Гагина-Скалон, 2016]. Характеристика особенностей динамики летней фауны куликов на Байкале приведена с учетом их распределения на прилежащих территориях на основе обобщающих публикаций разных авторов [Швецов, Швецова, 1967; Липин и др., 1968; Толчин, 1975; Толчин и др., 1977; Мельников, 1982; 2016а; 2016б; 2017; Сафронов, 1983; 1984; Васильченко, 1987; Богородский, 1989; Сумъяа, Скрябин, 1989; Ананин, 1991; Болд и др., 1991; Журавлев и др., 1991; Фомин, Болд, 1991; Фефелов и др., 2001; Бадмаева, 2006; Оловянникова, 2006; Попов, Матвеев, 2006; Малеев, Попов, 2007; Пыжьянов, 2007; Рябцев, 2007; Рябицев, 2014; Доржиев, 2011; Доржиев, Бадмаева, 2016; Мельников, Гагина-Скалон, 2016; MacKinnon et al., 2000; Fefelov, Tupitsyn, 2004; Mlikovsky, 2009].

Методологические подходы к изучению фауны куликов изложены нами в предыдущих публикациях [Мельников, 2004; 2008; 2011а; 2011б; 2014а; Мельни- 
Ю. И. Мельников. Динамика фауны куликов котловины озера Байкал и ее связь с современными изменениями климата (конец XVIII — начало XXI в.)

ков, Трошкова, 2016]. В пределах озера Байкал, исходя из его климатического деления, выделено три участка, достоверно различающихся по фауне птиц [Мельников, 2016а; Мельников, Гагина-Скалон, 2016]. Оценка статуса и обилия разных видов в пределах конкретного участка позволяла избежать субъективности при определении общего статуса любого вида. Вероятность ошибки возрастает, когда вид отмечается только на одном из участков Байкала, а такие ситуации, судя по общему количеству видов по участкам и всему оз. Байкал, являются наиболее обычными. Другая проблема возникает при оценке численности разных видов. Их обилие может определяться не столько популяционными изменениями их численности, сколько качественным состоянием местообитаний, пригодных для остановки куликов на отдых и гнездование. В зависимости от уровня обводнения численность пролетных и гнездящихся куликов может меняться многократно. Поэтому для общей оценки их обилия (на больших территориях: много, мало и т. д.) использовались материалы по северным и южным территориям с несовпадающей ритмикой природных процессов: повышенный уровень обводнения в южных регионах, на севере, в т. ч. и на Байкале, часто сопровождается маловодностью и наоборот [Мельников, 2011б; 2011в].

Показатель обилия видов определялся по частоте их встречаемости на местах миграционных и гнездовых концентраций: многочисленный вид отмечается на $65,0-85,0 \%$ маршрутов или обследованных участков, обычный $-35,0-64,0 \%$, редкий - 10,0-34,0\% и очень редкий - единичные встречи. Обилие видов определялось с учетом использования ими конкретных местообитаний и их площади. Более подробно методика изложена в предыдущей работе [Мельников, 2011б]. Определение статуса вида для каждого обследованного участка не вызывает затруднений. Для гнездящихся видов одновременно указывался и пролет, если он для них установлен. Это важно для южных видов, у которых часто фиксируется лишь прилет и только их появление в более северных районах указывает на пролет. В процессе обработки материала использовались стандартные методы его статистического анализа [Закс, 1976]. Порядок описания и систематика приведены по последним сводкам птиц России и Сибири [Коблик и др., 2006; Рябицев, 2014; Балацкий, 2018].

\section{Результаты}

За общий период изучения фауны куликов Восточной Сибири здесь было достоверно выявлено пребывание 63 видов [Мельников, 2011б], из них на оз. Байкал зарегистрировано 58 видов (табл.). Следовательно, фауна куликов этого озера фактически включает почти все виды данной группы, встречающиеся в Восточной Сибири. Отсутствуют только пять видов (морской песочник Calidris maritima, дупель Gallinago media, большой песочник Calidris tenuirostris, восточный веретенник Limosa melanuroides, украшенный чибис Lobivanellus indicus), отмеченных в этом огромном регионе исключительно в качестве очень редких залетных или эпизодически гнездящихся птиц (один-два раза за 50 лет). Указание на залет украшенного чибиса, возможно, является ошибочным [Фефелов, 2015; Мельников, 2017], однако он приводится в списке куликов Восточной Сибири [Гагина, 1974] и полностью отрицать его появление здесь нельзя, тем более что на Байкале встречаются птицы, обитающие в пределах основного ареала 
данного вида [MacKinnon et al., 2000]. Требуют уточнения и встречи восточного веретенника Limosa melanuroides, ранее относимого к восточному подвиду большого веретенника Limosa limosa melanuroides. На оз. Байкал отмечается номинативная форма данного вида либо переходная форма между западным и восточным подвидами [Фефелов и др., 2001; наши данные]. Однако далее на восток уже встречается восточный подвид, которому в настоящее время предложен статус вида восточный веретенник Limosa melanuroides Gould, 1846 [Балацкий, 2018].

В связи с этим трудно переоценить значение данного озера для формирования крупных остановочных пунктов куликов в периоды миграций. Озеро Байкал пересекают три крупных миграционных потока птиц, следующих на места гнездовий в Восточной Сибири, на п-ове Таймыр и Якутии и обратно на зимовки в Юго-Восточную Азию [Мельников, 2016а] (рис. 1). В устьях крупных рек (дельты р. Селенги, Верхней Ангары и Кичеры, устье р. Баргузин), впадающих в Байкал, формируются необходимые условия для крупных гнездовых концентраций куликов. Несмотря на это, их фауна и особенности ее формирования до сих пор описаны недостаточно подробно, а местами и поверхностно.

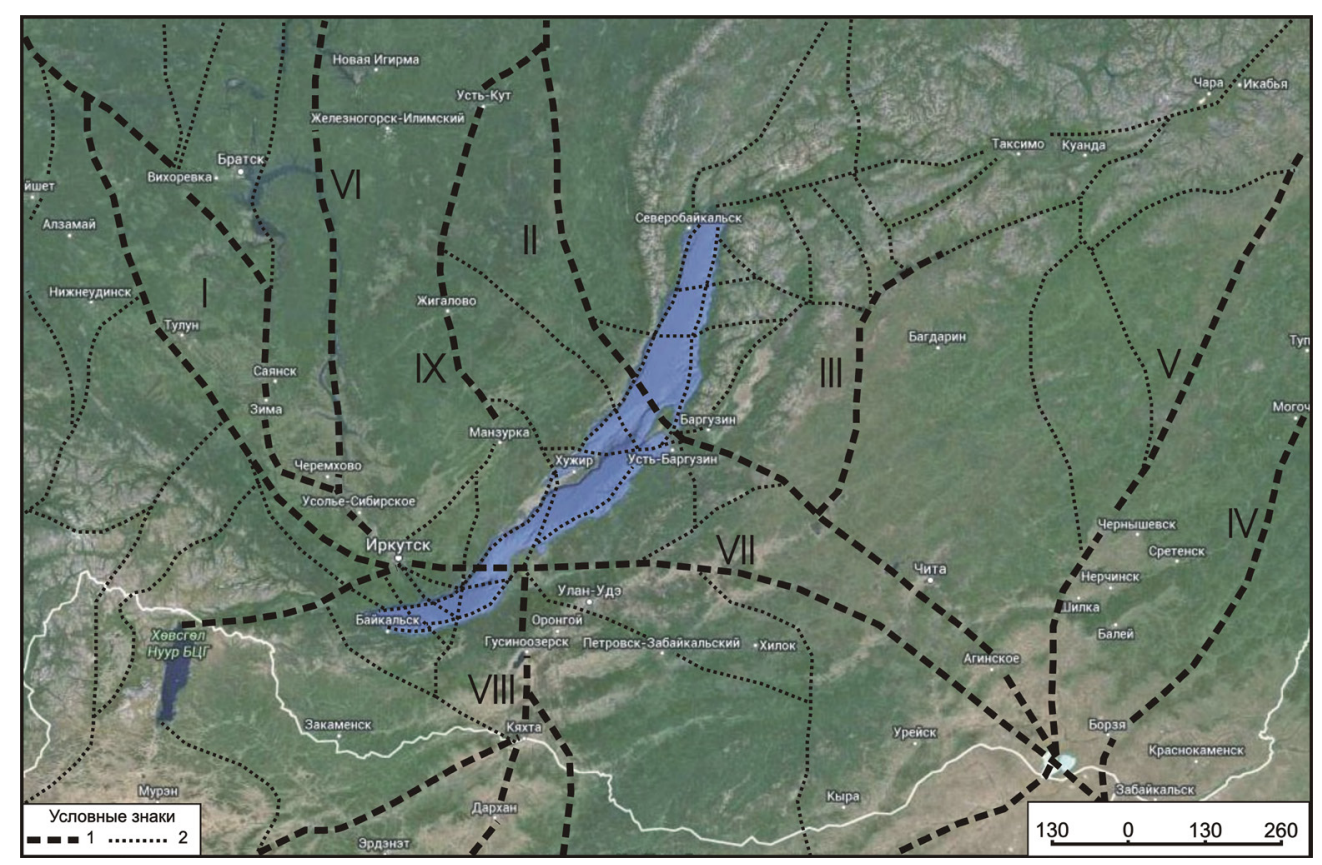

Рис. 1. Карта-схема основных путей миграций птиц Восточной Сибири [по Мельников, 2016а с дополнениями]

1 - Основные миграчионные пути: I - Байкало-Ангаро-Енисейский, II - Торейско-Киренгско-Тунгуссукий, III - Витимо-Патомский, IV - Хингано-Аргуно-Алданский, $V$ - Торейско-Олекминский, VI - Байкало-Ангаро-Тунгусский, YII - Торейско-БайкалоАнгарский, VIII - Селенгинский, IX - Байкало-Ленский. 2 - Второстепенные миграиионные пути. 
Ю. И. Мельников. Динамика фауны куликов котловины озера Байкал и ее связь с современными изменениями климата (конец XVIII - начало XXI в.)

Основная причина этого заключается в труднодоступности многих практически не обжитых участков данного озера. Лишь во второй половине XX в. были предприняты реальные усилия для детального изучения фауны птиц региона. На Байкале под руководством канд. биол. наук Н. Г. Скрябина (лаборатория «Экология наземных позвоночных животных» НИИ биологии при Иркутском госуниверситете) были налажены полноценные долговременные исследования экологии околоводных и водоплавающих птиц. Кроме того, подобные же исследования, но в меньшем объеме выполнялись в Бурятском государственном университете им. Д. Банзарова под руководством д-ра биол. наук, профессора Ц. З. Доржиева и специалистами Института общей и экспериментальной биологии БНЦ СО РАН (руководитель - известный паразитолог д-р биол. наук, профессор Н. М. Пронин). В результате специальных исследований были собраны обширные материалы по фауне и распределению птиц Байкала.

C конца XVIII по конец первой половины XX в. на Байкале было установлено пребывание 45 видов куликов. В то же время за второй период исследований (вторая половина XX - начало XXI в.) выявлено 57 видов этой группы околоводных птиц (табл.). Они включали всех ранее зарегистрированных куликов, за исключением перепончатопалого песочника Calidris mauri, отмеченного в конце XIX в. в районе д. Култук (Южный Байкал). Его залет в данную местность подтверждается коллекционными сборами Б. Дыбовского и В. Годлевского в окрестностях этого населенного пункта [Colston, 1975; Попов, 2009; Mlikovsky, 2009].

Таблица

Видовой состав и обилие куликов котловины озера Байкал с конца XVIII по начало XXI в. с учетом их распределения по климатическим округам (по: Мельников, Гагина-Скалон, 2016, с уточнениями)

\begin{tabular}{|c|c|c|c|c|c|c|}
\hline \multirow{3}{*}{ Вид } & \multicolumn{6}{|c|}{ Климатический округ } \\
\hline & \multicolumn{2}{|c|}{ Южно-Байкальский } & \multicolumn{2}{|c|}{ Средне-Байкальский } & \multicolumn{2}{|c|}{ Северо-Байкальский } \\
\hline & $\begin{array}{l}\text { первый } \\
\text { период }\end{array}$ & $\begin{array}{l}\text { второй } \\
\text { период }\end{array}$ & $\begin{array}{l}\text { первый } \\
\text { период }\end{array}$ & $\begin{array}{l}\text { второй } \\
\text { период }\end{array}$ & $\begin{array}{l}\text { первый } \\
\text { период }\end{array}$ & $\begin{array}{l}\text { второй } \\
\text { период }\end{array}$ \\
\hline Тулес Pluvialis & tr.r. & tr.r. & tr.r.aest.r & tr.c & tr.r. & tr.r. \\
\hline $\begin{array}{l}\text { Бурокрылая } \\
\text { ржанка } \\
\text { Pluvialis fulva }\end{array}$ & tr.c. & tr.r. & tr.c. & tr.C. & tr.r.(n).r & tr.c. \\
\hline $\begin{array}{l}\text { Золотистая } \\
\text { ржанка } \\
\text { Pluvialis apricaria }\end{array}$ & - & - & - & err.R. & - & err.R. \\
\hline $\begin{array}{l}\text { Галстучник } \\
\text { Charadrius hi- } \\
\text { aticula }\end{array}$ & - & tr.r. & - & tr.R. & aest.r. & tr.r. \\
\hline $\begin{array}{l}\text { Малый зуек } \\
\text { Charadrius dubius }\end{array}$ & tr.c.n.c. & tr.c.n.r. & tr.c.n.c. & tr.c.n.c. & tr.c.n.c. & tr.c.n.c. \\
\hline $\begin{array}{l}\text { Толстоклювый } \\
\text { зуек Charadrius } \\
\text { leschenaultii }\end{array}$ & - & - & - & err.R. & - & err.R. \\
\hline $\begin{array}{l}\text { Монгольский } \\
\text { зуек }\end{array}$ & - & - & - & err.R. & tr.r.(n).r. & err.R. \\
\hline
\end{tabular}




\begin{tabular}{|c|c|c|c|c|c|c|}
\hline $\begin{array}{l}\text { Charadrius mon- } \\
\text { golus }\end{array}$ & & & & & & \\
\hline $\begin{array}{l}\text { Восточный зуек } \\
\text { Charadrius ver- } \\
\text { edus }\end{array}$ & - & - & - & err.R. & err.R. & err.R. \\
\hline $\begin{array}{l}\text { Морской зуек } \\
\text { Charadrius alex- } \\
\text { andrinus }\end{array}$ & - & - & - & err.R. & - & err.R. \\
\hline $\begin{array}{l}\text { Хрустан Eu- } \\
\text { dromias morinel- }\end{array}$ & tr.R.n.R. & tr.R.n.R & tr.r. & err.R. & tr.r.n.r. & tr.r. \\
\hline $\begin{array}{l}\text { Чибис Vanellus } \\
\text { vanellus }\end{array}$ & tr.c.n.r. & tr.c.n.r. & tr.c.n.r. & tr.C.n.C & tr.r.n.r. & tr.C.n.c. \\
\hline $\begin{array}{l}\text { Серый чибис } \\
\text { Microsarcops ci- } \\
\text { nereus }\end{array}$ & - & - & - & err.R. & - & err.R. \\
\hline $\begin{array}{l}\text { Камнешарка } \\
\text { Arenaria inter- } \\
\text { pres }\end{array}$ & tr.R. & tr.R. & aest.R. & tr.r. & tr.r. & tr.R. \\
\hline $\begin{array}{l}\text { Ходулочник } \\
\text { Himantopus } \\
\text { himantopus } \\
\end{array}$ & - & err.R. & - & err.R. & - & - \\
\hline $\begin{array}{l}\text { Шилоклювка } \\
\text { Recurvirostra } \\
\text { avosetta }\end{array}$ & err.R. & tr.r. & tr.r.(n).r. & tr.r. & - & $\begin{array}{c}\text { tr.r.(n).r } \\
.\end{array}$ \\
\hline $\begin{array}{l}\text { Кулик-сорока } \\
\text { Haematopus os- } \\
\text { tralegus }\end{array}$ & - & tr.R. & - & - & - & - \\
\hline $\begin{array}{l}\text { Черныш Tringa } \\
\text { ochropus }\end{array}$ & tr.c.n.r. & tr.c.n.r. & tr.c.n.c. & tr.c.n.r. & tr.c.n.c. & tr.c.n.c. \\
\hline $\begin{array}{l}\text { Фифи Tringa } \\
\text { glareola }\end{array}$ & tr.c.n.c. & tr.c.n.r. & tr.c.n.c. & tr.C.n.r. & tr.c.n.c. & tr.C.n.c. \\
\hline $\begin{array}{l}\text { Большой улит } \\
\text { Tringa nabularia }\end{array}$ & tr.c.n.R. & tr.c. & tr.c. & tr.c.n.R & tr.c.(n).r. & tr.c.n.r. \\
\hline $\begin{array}{l}\text { Травник Tringa } \\
\text { totanus }\end{array}$ & - & tr.r. & aest.r. & tr.r. & - & tr.r. \\
\hline $\begin{array}{l}\text { Щеголь Tringa } \\
\text { erythropus }\end{array}$ & tr.aut.r. & tr.c. & tr.c.(n).C & tr.c. & tr.r. & tr.c. \\
\hline $\begin{array}{l}\text { Поручейник } \\
\text { Tringa stagnatilis }\end{array}$ & - & tr.c.n.r. & tr.r.n.r. & tr.C.n.C & tr.r.n.r. & tr.c.n.c. \\
\hline $\begin{array}{l}\text { Сибирский пе- } \\
\text { пельный улит } \\
\text { Heteroscelus } \\
\text { brevipes }\end{array}$ & tr.r.n.r. & tr.r. & aest.r. & tr.c. & tr.r.n.r. & tr.r. \\
\hline $\begin{array}{l}\text { Перевозчик Acti- } \\
\text { tis hypoleucos }\end{array}$ & tr.c.n.c. & tr.C.n.c. & tr.C.n.c. & tr.c.n.c. & tr.c.n.c. & tr.C.n.c. \\
\hline $\begin{array}{l}\text { Мородунка } \\
\text { Xenus cinereus }\end{array}$ & aest.r. & tr.r & $\begin{array}{l}\text { tr.aut.r. } \\
\text { aest.r. }\end{array}$ & tr.r. & aest.r. & tr.r. \\
\hline $\begin{array}{l}\text { Плосконосый } \\
\text { плавунчик Phal- } \\
\text { aropus fulicarius }\end{array}$ & - & - & - & err.R. & - & - \\
\hline
\end{tabular}


Ю. И. Мельников. Динамика фауны куликов котловины озера Байкал и ее связь с современными изменениями климата (конец XVIII — начало XXI в.)

\begin{tabular}{|c|c|c|c|c|c|c|}
\hline $\begin{array}{l}\text { Круглоносый } \\
\text { плавунчик Phal- } \\
\text { aropus lobatus }\end{array}$ & tr.R. & tr.r. & tr.R. & tr.r. & tr.aut.r. & tr.R. \\
\hline $\begin{array}{l}\text { Турухтан } \\
\text { Philomachus } \\
\text { pugnax }\end{array}$ & tr.r. & tr.c.n.r. & tr.c. & tr.c.n.c. & tr.r.(n).r & tr.c.n.r. \\
\hline $\begin{array}{l}\text { Кулик-воробей } \\
\text { Calidris minuta }\end{array}$ & tr.r. & tr.r. & tr.r. & tr.c. & tr.r. & tr.c. \\
\hline $\begin{array}{l}\text { Песочник- } \\
\text { красношейка } \\
\text { Calidris ruficollis }\end{array}$ & aest.r. & tr.r. & tr.r. & $\begin{array}{c}\text { tr.c.aest. } \\
\text { r. }\end{array}$ & aest.c. & tr.c. \\
\hline $\begin{array}{l}\text { Длиннопалый } \\
\text { песочник Calidris } \\
\text { subminuta }\end{array}$ & tr.r.(n).r. & tr.r.n.R. & tr.r. & tr.r.n.r. & tr.r. & tr.r.n.r. \\
\hline $\begin{array}{l}\text { Белохвостый пе- } \\
\text { сочник Calidris } \\
\text { temminckii }\end{array}$ & tr.c.aest.r. & tr.C. & $\begin{array}{l}\text { tr.r.(n).r. } \\
\text { aest.r. }\end{array}$ & tr.C. & tr.aut.r. & tr.C. \\
\hline $\begin{array}{l}\text { Бэрдов песочник } \\
\text { Calidris bairdii }\end{array}$ & - & - & - & - & - & err.r. \\
\hline $\begin{array}{l}\text { Бонопартов пе- } \\
\text { сочник Calidris } \\
\text { fuscicollis }\end{array}$ & - & - & - & err.r. & - & - \\
\hline $\begin{array}{l}\text { Краснозобик } \\
\text { Calidris ferrugi- } \\
\text { nea }\end{array}$ & tr.r. & tr.r. & tr.r. & tr.c. & $\begin{array}{l}\text { tr.R.aest. } \\
\text { r. }\end{array}$ & tr.c. \\
\hline $\begin{array}{l}\text { Чернозобик } \\
\text { Calidris alpina } \\
\end{array}$ & tr.r. & tr.r. & tr.r. & tr.c. & tr.r. & tr.c. \\
\hline $\begin{array}{l}\text { Острохвостый } \\
\text { песочник } \\
\text { Calidris acu- } \\
\text { minata }\end{array}$ & tr.R. & tr.r. & - & tr.r. & tr.aut.r. & tr.r. \\
\hline $\begin{array}{l}\text { Дутыш Calidris } \\
\text { melanotos }\end{array}$ & - & - & - & tr.r. & - & - \\
\hline $\begin{array}{l}\text { Исландский пе- } \\
\text { сочник Calidris } \\
\text { canutus }\end{array}$ & tr.r. & tr.r. & - & tr.R. & - & tr.r. \\
\hline $\begin{array}{l}\text { Перепончатопа- } \\
\text { лый песочник } \\
\text { Calidris mauri }\end{array}$ & err.R. & - & - & - & - & - \\
\hline $\begin{array}{l}\text { Песчанка } \\
\text { Calidris alba }\end{array}$ & tr.aut.r. & tr.r. & - & tr.r. & tr.aut.r. & tr.r. \\
\hline $\begin{array}{l}\text { Грязовик Limico- } \\
\text { la falcinellus }\end{array}$ & tr.R. & tr.r. & - & tr.r. & - & tr.r. \\
\hline $\begin{array}{l}\text { Гаршнеп Lym- } \\
\text { nocryptes minimus }\end{array}$ & - & tr.r. & tr.R.n.R. & tr.aut.r. & $\begin{array}{l}\text { tr.R.(n). } \\
\text { R. }\end{array}$ & tr.r. \\
\hline $\begin{array}{l}\text { Бекас Gallinago } \\
\text { gallinago }\end{array}$ & tr.C.n.c. & tr.C.n.c. & tr.r. & tr.C.n.c & tr.c.n.r. & tr.C.n.c. \\
\hline $\begin{array}{l}\text { Лесной дупель } \\
\text { Gallinago megala }\end{array}$ & tr.c.n.c. & tr.c.n.c. & tr.r.n.r. & tr.c.n.c. & tr.r.n.r. & tr.c.n.r. \\
\hline Азиатский бекас & tr.c.n.r. & tr.c. $(n) r$ & tr.c.n.r. & tr.c.n.r. & tr.c.n.c. & tr.c.n.c. \\
\hline
\end{tabular}




\begin{tabular}{|c|c|c|c|c|c|c|}
\hline $\begin{array}{l}\text { Gallinago stenu- } \\
\text { ra }\end{array}$ & & & & & & \\
\hline $\begin{array}{l}\text { Горный дупель } \\
\text { Gallinago solita- } \\
\text { ria }\end{array}$ & $\begin{array}{l}\text { tr.r.forc.win. } \\
\text { R. }\end{array}$ & $\begin{array}{l}\text { tr.r.forc.win. } \\
\text { R. }\end{array}$ & $\begin{array}{l}\text { aest.r. } \\
\text { forc.win. } \\
r\end{array}$ & tr.r. & tr.r.n.r. & $\begin{array}{l}\text { tr.r.n.r. } \\
\text { ac.win. } \\
\text { R. }\end{array}$ \\
\hline $\begin{array}{l}\text { Вальдшнеп } \\
\text { Scolopax rusticola }\end{array}$ & tr.c.n.r. & tr.c.n.c. & tr.c.(n).r. & tr.c.n.c. & tr.r.n.r. & tr.c.n.c. \\
\hline $\begin{array}{l}\text { Кроншнеп- } \\
\text { малютка } \mathrm{Nu} \text { - } \\
\text { menius minutus }\end{array}$ & tr.r. & tr.r. & tr.r. & tr.r. & tr.r.(n).r. & tr.r. \\
\hline $\begin{array}{l}\text { Тонкоклювый } \\
\text { кроншнеп } \\
\text { Numenius tenui- } \\
\text { rostris }\end{array}$ & - & - & - & (err.R)? & - & err.R. \\
\hline $\begin{array}{l}\text { Большой } \\
\text { кроншнеп } N u \text { - } \\
\text { menius arquata }\end{array}$ & tr.r.n.r. & tr.R.n.R. & tr.r.n.r. & tr.c.n.c. & tr.r.n.r. & tr.c.n.r. \\
\hline $\begin{array}{l}\text { Дальневосточ- } \\
\text { ный кроншнеп } \\
\text { Numenius mada- } \\
\text { gascariensis }\end{array}$ & err.R. & tr.r. & err.r. & tr.aut.r. & - & err.R. \\
\hline $\begin{array}{l}\text { Средний } \\
\text { кроншнеп } \mathrm{Nu} \text { - } \\
\text { menius phaeopus }\end{array}$ & tr.R. & tr.R. & - & tr.r. & - & - \\
\hline $\begin{array}{l}\text { Большой вере- } \\
\text { тенник Limosa }\end{array}$ & aest.r. & tr.r. & tr.r.n.R. & tr.C.n.c & tr.aut.r. & tr.r.n.r. \\
\hline $\begin{array}{l}\text { Малый веретен- } \\
\text { ник Limosa lap- } \\
\text { ponica }\end{array}$ & - & - & err.R. & err.R. & - & - \\
\hline $\begin{array}{l}\text { Американский } \\
\text { бекасовидный } \\
\text { веретенник Lim- } \\
\text { nodromus scolo- } \\
\text { paceus }\end{array}$ & - & - & - & tr.R. & - & - \\
\hline $\begin{array}{l}\text { Азиатский бека- } \\
\text { совидный вере- } \\
\text { тенник } \\
\text { Limnodromus } \\
\text { semipalmatus }\end{array}$ & - & tr.r. & $\begin{array}{l}\operatorname{tr} . \mathrm{R} .(\mathrm{n}) . \\
\text { R. }\end{array}$ & tr.r.n.r. & - & tr.r.n.r. \\
\hline $\begin{array}{l}\text { Восточная тир- } \\
\text { кушка } \\
\text { Glareola maldi- } \\
\text { varum }\end{array}$ & - & - & - & err.r. & - & - \\
\hline Всего & 37 & 43 & 36 & 55 & 36 & 48 \\
\hline
\end{tabular}

Примечание: статус вида: n. - гнездящийся, (n). - гнездование требует подтверждения, tr. -пролетный, err. - залетный, aest. - летующий, tr.aut. - встречается только на осеннем пролете, forc.win. - вынужденно зимующий обычный, ac.win. - вынужденно зимующий случайный или очень малочисленный. Обилие вида: $\mathrm{R}$ - очень редкий, r - редкий, c - обычный, C - многочисленный. 
Ю. И. Мельников. Динамика фауны куликов котловины озера Байкал и ее связь с современными изменениями климата (конец XVIII — начало XXI в.)

По количеству куликов, зарегистрированных в разных климатических округах Байкала, хорошо выделяется Средне-Байкальский округ (55 видов). Это явно обусловлено большой площадью водно-болотных угодий в данном регионе, который включает дельту р. Селенги, Баргузинский залив и острова пролива Малое Море, а также несколько более мелких притоков, имеющих при впадении в Байкал мелководные устья рек. Несколько меньше куликов зарегистрировано в Северо-Байкальском климатическом округе (48 видов), также имеющем большую площадь мелководных прибрежных местообитаний: Чивыркуйский залив с озером Арангатуй и дельты рек Верхняя Ангара и Кичера. Южно-Байкальский округ имеет небольшую площадь прибрежных мелководий и здесь зарегистрировано наименьшее количество куликов (43 вида) (табл. и рис. 2). В общей структуре фауны куликов оз. Байкал в первый период исследований гнездящиеся виды составляли $37,8 \%$, пролетные - 42,2\%, залетные - 8,9\%, летующие - 6,7\% и встречающиеся только на осеннем пролете - 4,4\% из зарегистрированных 45 видов. Во второй период исследований доля гнездящихся видов составляла $31,6 \%$, пролетных - 42,1\%, залетных - 22,8\% и встречающихся только на осеннем пролете - 3,5\% из 57 видов, встреченных в данное время (рис. 2).

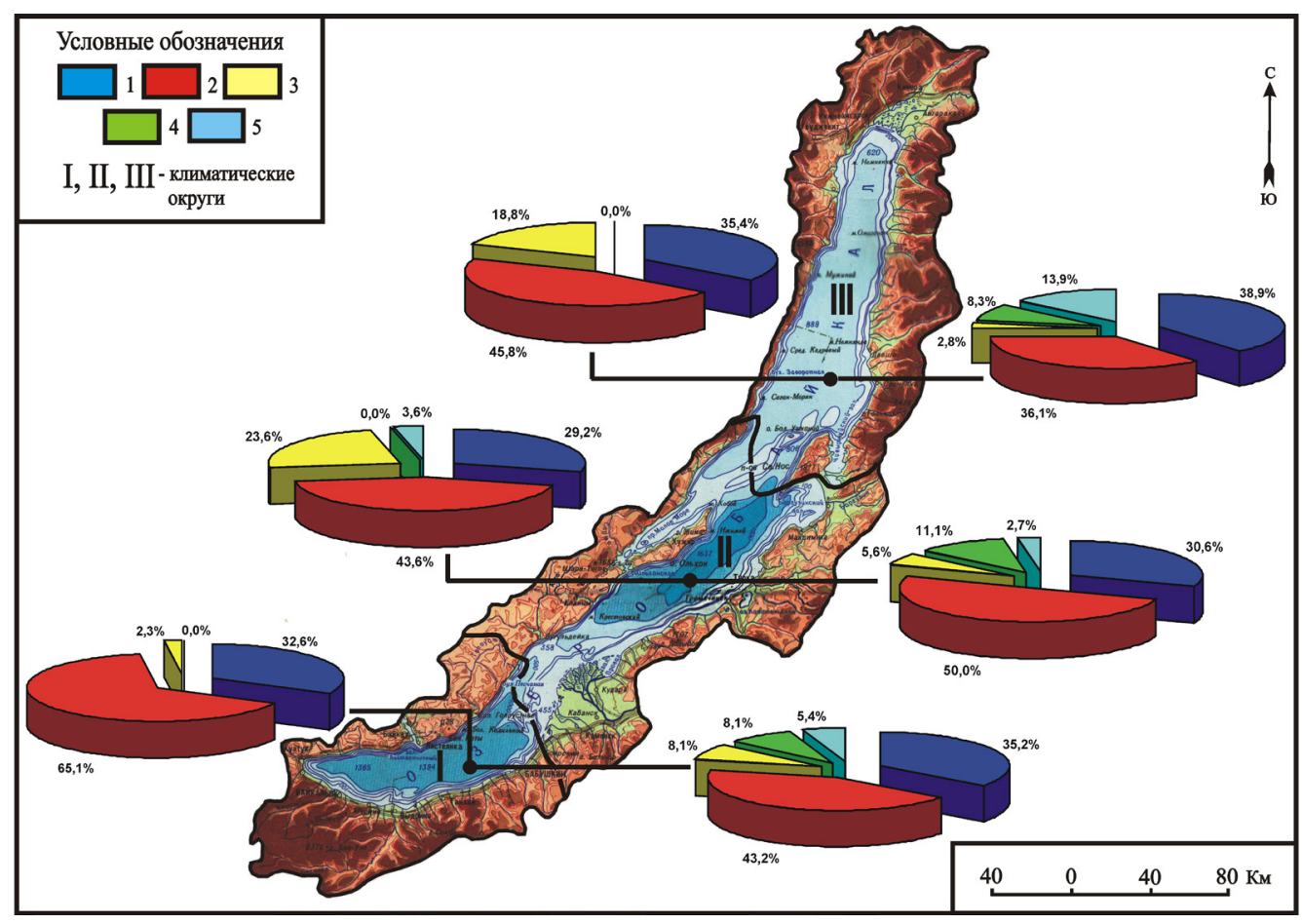

Рис. 2. Динамика структуры фауны куликов оз. Байкал в зависимости от изменений климата (конец XIX - начало XXI в.)

Климатические округа: I - Южно-Байкальский, II - Средне-Байкальский, III - Северо-Байкальский. справа - результать I периода исследований, слева - результаты II периода работ. Структурные категории фауны куликов, вид: 1 - гнездящийся, 2 - пролетный, 3 - залетньй, 4 - летующий, 5-встречающийся только во время осенней миграции. 
Изменения в количестве разных видов куликов, зарегистрированных по климатическим округам Байкала, как в первый, так и во второй периоды исследований наблюдаются во всех категориях данной группы птиц (рис. 2). Хорошо видно, что количество категорий куликов было явно выше в первый период исследований. Причина этого достаточно очевидна - в это время обычными были категории летующих и встречающихся только во время осенней миграции куликов (рис. 2). Однако во второй период работ эти категории не встречались в Южно-Байкальском и Северо-Байкальском климатических округах, а в СреднеБайкальском их доля была минимальной (виды, встреченные только во время осенней миграции) (рис. 2).

Основная причина - степень изученности фауны куликов и отчасти уровень видового разнообразия птиц конкретного района Байкала. Большая часть птиц, зарегистрированных в двух последних категориях в первый период работ, перешла во второй период в категории с более определенным статусом — чаще всего пролетных и залетных видов. Очевидно, их статус в начале исследований был выявлен неточно, что определенно может быть связано с интенсивностью обследования территории. В таких случаях очень малочисленные виды птиц обычно попадают в данные категории. По мере увеличения степени изученности фауны статус птиц уточняется, что приводит к их переводу в другие, более определенные категории. В районах с высоким видовым разнообразием птиц вероятность встреч таких видов явно выше, что подтверждается их регистрацией в СреднеБайкальском климатическом округе и во второй период исследований.

Наиболее очевидны существенные изменения в количестве гнездящихся и залетных видов куликов во второй период исследований. Их количество явно увеличилось у залетных видов (рис. 2), что подчеркивает специфическое влияние потепления климата на фауну птиц озера Байкал. Однако по разным округам эти изменения были различными. В Южно-Байкальском округе существенно увеличилась доля пролетных видов (в 1,5 раза), но сократилась доля залетных птиц (в 3,5 раза). Средне-Байкальский округ, имеющий высокую долю продуктивных водно-болотных угодий, отличается небольшим сокращением доли пролетных куликов (в 1,1 раза), но существенным ростом доли их залетных видов (в 4,2 раза). Однако в Северо-Байкальском округе доля пролетных видов по сравнению с предшествующим периодом увеличивается, но не очень сильно (в 1,3 раза), а доля залетных птиц резко возрастает (в 6,7 раза). Характерно, что доля гнездящихся птиц в оба периода по всем округам меняется очень мало (рис. 2). Явно прослеживается тенденция к уменьшению доли залетных видов с юга на север в первый период исследований, но сильное увеличение доли этой же категории куликов в данном направлении во второй период работы.

Выявленные различия в фауне куликов по разным периодам исследований и климатическим округам Байкала не вызывают сомнений - мы имеем дело с генеральными совокупностями. Однако динамика количества видов в разных категориях птиц может интерпретироваться по-разному. Очевидно, нужна дополнительная статистическая проверка выявленных закономерностей, тем более что в таком случае нам необходимо рассматривать уже не полную совокупность видов, а отдельные их группы. Сравнение частот распределений видов по разным категориям птиц по округам (использовался критерий Брандта-Снедекора) [Закс, 
Ю. И. Мельников. Динамика фауны куликов котловины озера Байкал и ее связь с современными изменениями климата (конец XVIII — начало XXI в.)

1976] показало, что различия в фауне куликов за оба периода наблюдений в целом являются достоверными. По разным периодам работ они отсутствуют только в Южно-Байкальском округе - $\chi^{2}=8,9<9,5 \chi^{2} 4 ; 0,05$, хотя они здесь очень близки к критическому значению. В Средне-Байкальском округе различия уже достигают критических значений $\chi^{2}=10,7>9,5 \chi^{2} 4 ; 0,05$, а в Северо-Байкальском являются высокодостоверными $-\chi^{2}=15,6>13,3 \chi^{2} 4 ; 0,01$. Отличия в составе фауны по различным категориям птиц возрастают с юга на север, так как между округами в этом направлении увеличивается достоверность различий. Очевидно, различия в составе категорий птиц разных климатических округов по периодам исследований во многом определяются жесткостью климатических условий. В то же время нельзя исключать и влияние расселения куликов с разных направлений, поскольку доля залетных птиц во второй период работ также явно увеличивается к северной оконечности озера Байкал.

Дополнительная проверка распределения количества видов птиц в общей фауне оз. Байкал по категориям, но в разных климатических округах на независимость и однородность с использованием таблиц сопряженности признаков типа $\mathrm{r}$ x c [Закс, 1976] показала, что в первом периоде наблюдений изменения с юга на север недостоверны $-\chi^{2}=5,6<15,5 \chi^{2} 8 ; 0,05$. Во второй период исследований различия между округами в количестве видов по разным категориям куликов достигают критических значений и достоверны $-\chi^{2}=15,8>15,5 \chi^{2} 8$; 0,05. Следовательно, общая тенденция к увеличению доли залетных видов куликов на оз. Байкал с юга на север во второй половине XX - начале XXI в., отмеченная нами выше, является несомненной и достоверной. Однако причины этого требуют дополнительного анализа, поскольку данная проблема явно не исчерпывается только потеплением климата. Необходимо отметить, что тенденции к изменению фауны куликов, выявленные среди различных их категорий в разные периоды исследований, в целом характерны для основной части птиц оз. Байкал [Мельников, 2016а; 2017; 2018].

Существование очень крупных потоков птиц, мигрирующих через оз. Байкал, подтверждается детальными многолетними наблюдениями [Мельников, 2016а]. Особой мощностью отличается Байкало-Ангаро-Енисейский пролетный путь (рис. 1), формирующийся в результате слияния двух миграционных путей - Ceленгинского и Торейско-Байкало-Ангарского. Здесь в связи с присутствием обширных лесостепных регионов и крупных водных артерий (р. Селенги и Ангары) миграция птиц весной начинается очень рано, а пролетный поток отличается высокой мощностью. Охватывая южные регионы Забайкалья, эти пролетные пути обеспечивают раннее начало миграции в обход крупных горных систем (Восточные Саяны, Икатский, Баргузинский и Байкальский хребты). Менее мощный Торейско-Киренгско-Тунгусский поток проходит через Арангатуйские озера, Чивыркуйский и Баргузинский заливы оз. Байкал. По северной оконечности этого озера проходит Витимо-Патомский пролетный путь, формирующийся из нескольких относительно небольших миграционных потоков. Он обеспечивает преодоление крупных горных систем Северного Байкала во второй половине миграции, когда она может идти через удобные перевалы (рис. 1). В связи с обширной сетью пролетных путей и огромными размерами озера выселяющиеся виды куликов попадали на Байкал с разных направлений (в зависимости от локализа- 
ции крупных засух), чем и обусловлен их сложный и разнообразный видовой состав.

\section{Обсуждение}

При анализе собранных материалов прежде всего отмечается резкое различие в количестве видов куликов, зарегистрированных в котловине озера Байкал в разные периоды исследований (45 и 57 видов, общее количество куликов в Восточной Сибири в настоящее время - 63 вида). Именно это послужило поводом считать, по мнению некоторых авторов, что недостаточно изучена фауна птиц, в т. ч. и куликов, в конце XIX - первой половине XX в. [Преловский, 2011]. Между тем, как нами уже указывалось, обследование региона было вполне удовлетворительным. Его посетили многие известные путешественники и исследователи, собравшие обширный материал по фауне этой группы птиц и опубликовавшие крупные обзорные статьи и монографии [Дыбовский, Годлевский, 1870; Тачановский, 1877; Туров, 1923; Воробьев, 1927; Третьяков, 1934; Georgi, 1775; Maak, 1859; Radde, 1863; Taczanowski, 1893; Stegmann, 1929; 1936; Гагина, 1961].

В данном случае мы считаем необходимым подчеркнуть, что, вопреки мнению В. А. Преловского (2011), собранный материал позволяет хорошо охарактеризовать общую динамику фауны куликов озера Байкал. Многолетние исследования показывают, что за 5-7 лет можно выявить основное ядро фауны птиц [Мельников, 2011б; 2011в]. За такой значительный период времени видовой состав куликов был выявлен достаточно полно. Другое дело, что численность многих птиц из-за суровых климатических условий была очень низкой и статус ряда видов определен неверно. Это подчеркивается присутствием таких категорий видов, как зарегистрированные только на весеннем или осеннем пролете, залетные, летующие и т. д. Необходимо обратить внимание и на то, что во второй половине исследований доля таких видов резко сократилась, а многие очень редкие птицы даже получили статус пролетных и гнездящихся видов (табл. 1).

Сравнительно небольшое количество видов куликов, зарегистрированных в первый период исследований, отражает не уровень их изученности, а суровые условия обитания птиц данной группы в это время в Северной Азии. Специальные исследования показали, что на первый период работ приходится третья фаза малого ледникового периода - 1640-1840 гг., отличающаяся очень сильным похолоданием. По окончании наблюдается слабо выраженное потепление на суше. В то же время малый ледниковый период в ярко выраженной форме был характерен только для Западной Европы. При этом покровного оледенения в это время здесь не было (за исключением горных систем), но преобладали низкие температуры приземного слоя воздуха, а данный период отличался очень сильным увлажнением [Леви и др., 2017]. Разумеется, такое похолодание распространялось, правда в меньшей степени, и на прилежащие территории.

В Восточной Европе и азиатских странах (по некоторым из них имеются данные) выраженное похолодание наблюдалось несколько позже и было заметно короче [Леви и др., 2017], хотя прослеживалось по всему Северному полушарию Земли. На это время, вероятно, из-за снижения теплоотдачи Гольфстримом, а также недостатка инсоляции океана и земной поверхности, приходится постепенное нарастание площади ледового покрова всей Арктики, которое продлилось 
Ю. И. Мельников. Динамика фауны куликов котловины озера Байкал и ее связь с современными изменениями климата (конец XVIII — начало XXI в.)

до конца первой половины 20-го столетия [Леви и др., 2017]. В связи с этим в континентальной части Сибири этот период не мог быть теплым, что отражалось и на составе фауны птиц. Некоторая часть видов, включая и куликов, перемещалась для гнездования из тундровой зоны в более южные районы, что приводило к существенным изменениям границ их ареалов.

Необходимо помнить, что вся первая половина XX в. в Восточной Сибири климатологами относилась к позднеледниковью [Мухина и др., 1965] и, следовательно, не могла отличаться богатством фауны прибрежных птиц. Это положение полностью подтверждается составом фауны куликов в этот период - он значительно беднее по сравнению с современным, практически не содержит типично южных видов. Специальная работа, выполненная на примере куликов Оренбургских степей, также подчеркивает именно этот аспект проблемы - в конце 19-го столетия здесь встречались на протяжении всего лета и с высокой вероятностью гнездились типично тундровые виды куликов (плосконосый и круглоносый плавунчики, кулик-воробей и грязовик) [Тарасов, Коршиков, 2018]. В данном случае необходимо отметить и летние встречи, возможно, и гнездование отдельных пар в Западной Сибири на северных окраинах лесостепи малого веретенника, также типично тундрового вида куликов [Словцов, 1892; Гладков, 1951]. Следовательно, такие различия в видовом составе куликов, выявленные в разные периоды наблюдений, отражают последовательное потепление климата, наблюдавшееся после окончания периода его существенного похолодания.

При анализе изменений приземной температуры воздуха и увлажненности за первую половину XX в. выявлено на территории СССР четыре крупных климатических очага [Афанасьев, 1967]. Восточная Сибирь как географический регион относится к этим очагам. Последнее подтверждается и современными данными. На фоне общего потепления климата северного полушария Земли озеро Байкал, следовательно, и прилежащие к нему территории отличаются более значительным повышением температуры воздуха. Потепление в этом регионе было более чем в два раза значительнее - $1,9^{\circ} \mathrm{C}$ за 100 лет, чем в среднем по северному полушарию Земли $-0,7^{\circ} \mathrm{C}$ за 100 лет [Шимараев и др., 2008; Шимараев, Старыгина, 2010; Жеребцов и др., 2011; 2013; Латышева и др., 2011; Бережных и др., 2012]. Резкое потепление во второй половине 20-го столетия на Байкале было выражено четко и прошло за более короткое время по сравнению с предшествующим периодом похолодания климата [Мельников, 2016а].

Влияние потепления климата на северные границы ареалов птиц, в т. ч. и куликов, на территории России было зафиксировано в самом начале второй половины прошедшего столетия [Сыроечковский-ст., 1960]. Основная часть куликов - типичные животноядные виды (в основном зондировщики), а обилие бентоса зависит от факторов физической среды. В более теплых водах обилие животных кормов намного выше по сравнению с холодными [Кривенко, Виноградов, 2008]. Именно этими причинами обусловлены и высокие различия в общем составе фауны куликов, зарегистрированные в данные периоды исследований. Новые виды этой группы птиц, появившиеся на Байкале во второй половине 20-го столетия, представлены типичными птицами Центральной Азии (Монголия и Китай), включающими толстоклювого и морского зуйков, серого чибиса, шилоклювку, ходулочника и восточную тиркушку. В результате расширения ареа- 
лов на восток отмечены на Байкале кулик-сорока и тонкоклювый кроншнеп. Находки последнего вида, в связи с его экстремально низкой численностью, интерпретировать довольно сложно. Это могли быть и случайные залеты, обусловленные резким изменением качества исходных гнездовых местообитаний как в результате естественных причин (обсыхание), так и интенсивного антропогенного воздействия [Мельников, 2017].

В то же время очень редкие регистрации некоторых малочисленных северных видов куликов могут быть обусловлены изменениями путей миграций в результате современной динамики ареалов (расширения их в тундровой зоне на восток или запад) (золотистая ржанка и американский бекасовидный веретенник) [Бадмаева, 2006; Мельников, 1998; 2004a; 2009; 2010; 2011б; Мельников, ГагинаСкалон, 2016; Yelayev, 2017]. В данном случае необходимо упомянуть и дупеля Gallinago media, не достигающего оз. Байкал, но временами гнездившегося под г. Иркутском [Мельников, 2011в]. Для некоторых видов с незначительной численностью на миграционных путях Восточной Сибири отмечены только единичные регистрации - плосконосый плавунчик [Толчин и др., 1977]. Для ряда чрезвычайно редких видов куликов, эпизодически появляющихся на Байкале, наиболее вероятны климатические аномалии в тундровой зоне или на путях пролета, вплоть до случайных заносов сильными арктическими и североатлантическими воздушными потоками (Бэрдов и Бонапартов песочники, дутыш) [Мельников, 2011б; 2016а; 2017; 2018; Мельников, Гагина-Скалон, 2016; Доржиев и др., 2018 ]. В последних случаях это несомненный результат сильных изменений атмосферной циркуляции и увеличения частоты повторения экстремальных погодных ситуаций. Они наиболее характерны для последних десятилетий прошедшего и начала текущего столетий [Жеребцов и др., 2011; 2013].

Общая схема атмосферной циркуляции в Восточной Сибири в современный период изложена в специальных публикациях [Шимараев и др., 2008; Шимараев, Старыгина, 2010; Жеребцов и др., 2011; 2013; Бережных и др., 2012; Латышева и др., 2011; Мельников, 2016а]. Для северного полушария Земли характерно, что в середине прошедшего столетия в Африке и южных регионах Азии прошла серия сильных и обширных засух, постепенно перемещающихся с запада на восток [Кошеленко, 1983; Леви и др., 2003; Мельников, 2004a; 2009; 2010]. Во второй половине этого столетия частота их проявления заметно увеличилась, а в 60-х годах в восточных районах России и прилежащих к ним странах они стали повторяться ежегодно, постоянно перемещаясь по южным регионам Северной Азии и охватывая обширные их площади. Критическая ситуация сложилась в 1975-1977 гг. - обширные засухи отмечены на значительной территории Китая, Монголии и южных районов Восточной Сибири [Кошеленко, 1983; Леви и др., 2003; Мельников, 2004a; 2009; 2010; 2011a; 2011б; 2011в; 2013; 2014; 2015; 2016а; 2016б; 2017; 2018]. В отдельные годы они охватывали практически всю Монголию и большую часть Китая [Кошеленко, 1983; Мельников, 2004a; 2009; 2016a; Cheng, 1978; Ofori-Sarpong, 1980].

Первые этапы выселения куликов из Центральной Азии зафиксированы в конце 50-х — начале 60-х гг. прошедшего столетия. В это время на Южном и Среднем Байкале (дельта р. Селенги и Чивыркуйский залив) зафиксировано появление азиатского бекасовидного веретенника, а также массовые выселения по- 
Ю. И. Мельников. Динамика фауны куликов котловины озера Байкал и ее связь с современными изменениями климата (конец XVIII — начало XXI в.)

ручейника, чибиса, белокрылой крачки Chlidonias leucopterus, серой утки Anas strepera и черной кряквы Anas poecilorhyncha [Скрябин, 1967; 1975; Измайлов, Боровицкая, 1973; Толчин, Мельников, 1974; 1977; Толчин, 1984; Толчин и др., 1977; Мельников, 2004а; 2009; 2010; Доржиев, 2011]. Несколько позже наблюдались массовые выселения далеко к северу азиатского бекасовидного и большого веретенников, большого и дальневосточного кроншнепов, а также регистрировались единичные встречи редких и малочисленных южных, преимущественно степных, лугово-болотных видов куликов: шилоклювка, ходулочник, травник [Толчин, Мельников, 1974; 1977; Мельников, 2000; 2004a; 2009; 2010; 2011a; 2011в; Доржиев, Елаев, 1999; Доржиев, 2011].

В середине 70-х гг. прошлого столетия на Байкале зафиксировано значительное повышение плотности населения и численности массовых луговоболотных видов куликов и продвижение к северу оптимумов ареалов чибиса, турухтана, фифи, поручейника, большого улита, большого веретенника, большого кроншнепа, бекаса, азиатского бекаса, лесного дупеля и др. [Липин и др., 1968; Толчин, Мельников, 1974; 1976; Толчин, 1976а; 1976б; 1984; Мельников, 1998; 2004а; 2009; 2011б; 2011в; 2014; 2015; 2016а; 2016б; 2017; Доржиев, Елаев, 1999; Фефелов и др., 2001; Малеев, Попов, 2007; Рябцев, 2007; Мельников, ГагинаСкалон, 2016; Fefelov, Tupitsyn, 2004]. Плотность их населения на Байкале и прилежащих районах Прибайкалья резко увеличилась (в 3-4, иногда в 10 раз). Некоторые виды продвинули северные границы ареалов вплоть до Центральноякутской низменности (чибис, поручейник, большой веретенник и др.) и пошли далее к северу, где они в благоприятных местах достигали достаточно высокой плотности населения [Дегтярев, 2007; Лаппо и др., 2012; Романов, 2013].

Однако уже в 80-х годах прошедшего столетия интенсивность засух и частота их повторения заметно снизились - отмечались небольшие по площади засухи в гобийских аймаках Монголии, автономной области Внутренняя Монголия (КНР) и прилежащих районах России. Однако за прошедшие 10 лет здесь шло формирование новых лугово-болотных местообитаний, пригодных для гнездования птиц при другом (значительно более низком) уровне воды водно-болотных экосистем [Мельников, 2009; 2010; 2015; Mel'nikov, 2005; 2016]. Значительная часть птиц стала оставаться на прежних местах гнездования, и интенсивность выселений (миграций) снизилась (Мельников, 2009). В то же время сохранившаяся тенденция к потеплению климата привела к постепенному установлению в Центральной Азии очень длительного маловодного периода [Новороцкий, 2006; Бережных и др., 2012; Кирилюк и др. 2012; Обязов, 2012; Mel'nikov, 2005; 2016].

Данный период отличался значительными выселениями к северу водоплавающих птиц и массовых видов куликов. Особенно ярко данная тенденция проявилась в начале 21-го столетия [Мельников, 2014]. Характерно резкое снижение плотности гнездования всех массовых видов лугово-болотных куликов в Прибайкалье и на оз. Байкал. Это обусловлено практически полным обсыханием заболоченных лугов и пойм степных рек вплоть до северной границы лесостепи и южной тайги [Кирилюк и др., 2012; Мельников, 2014а]. В частности, в Даурском экорегионе в период максимального развития тепло-сухой фазы климата обсохло 90,0-98,0\% мелких степных озер, а крупные речные водотоки лишились большинства притоков [Ткаченко, Обязов, 2003; Кирилюк и др., 2012]. Кроме того, 
эта тенденция сопровождалась выселениями к северу (до Байкала и далее) птиц типичных пустынь и степей, а также высокогорных экосистем, которые не отличались массовостью - основная часть видов встречалась только залетами (зуйки, жаворонки, каменки, грифы и стервятники), но ранее в волнах выселений данные группы птицы отмечались чрезвычайно редко [Мельников, 2017; 2018]. Некоторые виды степных видов куликов стали гнездиться в Прибайкалье, в т.ч. и северном (шилоклювка, ходулочник, восточный зуек), хотя на Байкале их гнездование до сих пор не было установлено [Бадмаева, 2006; Мельников, 2015; Доржиев и др., 2018]. Возможно, это связано с резким снижением интенсивности орнитологических исследований в современный период.

Особый интерес вызывает реакция птиц, гнездившихся на Байкале в первой половине 20-го столетия (позднеледниковье), на современную климатическую ситуацию. Наиболее показательны в этом отношении виды, имевшие ранее в Восточной Сибири обширные ареалы. Прежде всего это относится к большому улиту, встречавшемуся повсеместно [Гагина, 1961]. Последние находки его гнездовых пар и птенцов в дельте р. Селенги относятся к 1981 г. [Мельников, 1984]. В настоящее время он гнездится только на северном Байкале в поймах Кичеры и Верхней Ангары на болотах подгорного шлейфа, но на его побережье не выходит, во всяком случае он здесь до сих пор в гнездовое время обнаружен не был. В небольшом количестве большой улит встречается на гнездовье в северных регионах Восточной Сибири. Практически исчезла и фифи - на Байкале не ежегодно отмечаются только единичные гнездовые пары этого вида. Редка она и на других участках ареала данного региона, даже там, где ранее нами отмечались десятки пар этого вида. Для основной части массовых видов, прежде всего чибиса, черныша, бекаса, азиатского бекаса и лесного дупеля, характерно резкое снижение плотности населения на южных участках ареалов, также как и для турухтана, поручейника, большого веретенника и большого кроншнепа [Мельников, 2004; 2009; 2014a; 2016б].

В настоящее время степные и южные лугово-болотные виды куликов регистрируются на гнездовье, преимущественно в лесостепи, хотя есть и определенная тенденция к поддержанию северных новых гнездовых очагов. Однако основная часть таких видов резко изменила положение оптимумов ареалов. На юге Восточной Сибири и на Байкале встречаются только отдельные гнездящиеся пары и небольшие группы этих видов, даже в тех местах, где они ранее были массовыми и фоновыми видами птиц. В настоящее время у этих видов просматривается хорошо выраженное смещение оптимумов ареалов к северу, в некоторых случаях за пределы Восточной Сибири. В ее южных регионах сохранились отдельные очаги их гнездования с низкой плотностью населения, которая постепенно увеличивается к северу, по мере повышения численности гнездящихся птиц. Ареалы этих видов сейчас имеют вид шлейфов, идущих к местам массового гнездования на севере, с постепенно повышающейся плотностью населения, подобно современному ареалу турухтана в Западной Сибири, описанному несколько ранее [Тарасов, Коршиков, 2018].

К случайному гнездованию на миграционном пути следует отнести находку нелетных птенцов щеголя в дельте р. Селенги в 1981 г. [Мельников, 1984]. Это сезон резкого обмеления дельты в весенний период из-за снижения уровня воды 
Ю. И. Мельников. Динамика фауны куликов котловины озера Байкал и ее связь с современными изменениями климата (конец XVIII — начало XXI в.)

на р. Селенге. Обнажившиеся нижние участки дельты имели вид тундроподобных ландшафтов, а численность щеголя, державшегося здесь в течение всего лета, была аномально высокой - 100-120 особей (ранее встречались отдельные пары и группы из 3-5 птиц) [Мельников, 1984]. Случаи гнездования у типично тундровых видов птиц на путях миграций и их причины детально рассмотрены в специальной публикации [Тарасов, Коршиков, 2018] и нами здесь не рассматриваются.

Чрезвычайно интересным является неожиданное появление азиатского бекасовидного веретенника далеко на севере в среднем течении р. Вилюй (Сунтарский улус). Численность птиц была достаточно высокой (в двух стаях в середине лета 48 и 86 птиц), они явно здесь или где-либо поблизости гнездились [Афанасьев, 2018]. Из какой части ареала они попали сюда - вопрос проблематичный. Однако необходимо отметить, что в верховьях Вилюя и в его средней части обычно встречаются птицы, летящие через Западно-Сибирскую равнину, что подтверждается и результатами массовых кольцеваний, в т. ч. и куликов [Мельников, 1999]. Поэтому не исключено, что это азиатские бекасовидные веретенники степных районов Западной Сибири, выселившиеся далеко на север. Восточные очаги гнездования данного вида на территории России в настоящее время полностью деградировали. Более вероятно гнездование этого вида из этой части ареала где-либо на новых благоприятных участках основного ареала в Монголии и Китае. Этот кулик может на сравнительно небольшой площади формировать чрезвычайно крупные гнездовые концентрации, объединяющие до 50,0-80,0\% особей вида [Мельников, 2003; 2004б; 2010].

В целом современные особенности распространения куликов Восточной Сибири неплохо укладываются в концепцию циклической динамики ареалов водоплавающих птиц, обусловленных изменениями климата в циклах не ниже векового, вероятнее всего, многовекового уровней, разработанную В. Г. Кривенко (1991). По мере изменений климата в крупных климатических циклах (прежде всего многовековых, продолжительностью от 1500 до 2200 лет), имеющих две ярко выраженные фазы - тепло-сухую и влажно-холодную, околоводные и водоплавающие птицы смещают оптимумы ареалов на юг (влажно-холодный период) или на север (тепло-сухой период). В настоящее время с высокой вероятностью заканчивается тепло-сухая фаза многовекового цикла климата продолжительностью около 2000 лет [Кривенко, 1990; Кривенко, Виноградов, 2008; Воронин и др., 2014; Мельников, 2016а; 2018]. В связи с этим оптимумы ареалов основной части видов этой группы птиц ушли далеко на север, а у южных более малочисленных видов сместились к северной границе лесостепи.

Необходимо отметить, что такая динамика ареалов присуща и некоторым другим группам птиц, но для них более характерны широтные перемещения в поисках подходящих местообитаний, т. е. они перемещаются прежде всего в своей природной зоне и лишь незначительная часть птиц выселяется к северной границе своей зоны [Мельников, 2018]. Четко выраженные перемещения югсевер-юг характерны для околоводных и водоплавающих птиц. Они осваивают своеобразные водно-болотные местообитания, которые являются интразональными и встречаются во всех природных зонах и горных поясах, что и обеспечивает такие перемещения птиц этой группы [Мельников, 2017; 2018]. 
Вполне очевидно, что интенсивность и масштабность подобной динамики ареалов полностью определяется степенью выраженности конкретных фаз климата. В наибольшей степени они проявляются в очень больших многовековых циклах. В настоящее время заканчивается шестой, наиболее документированный, цикл этого уровня [Шнитников, 1957; Кривенко, 1991; Кривенко, Виноградов, 2008; Воронин и др., 2014; Мельников, 2016а; 2017; 2018]. Однако полноценное сравнение циклов данного уровня между собой невозможно - основная часть сведений получена косвенными методами. Возможны только сравнения по степени выраженности экстремальных ситуаций. В связи с этим полноценные сведения, полученные в современную эпоху, будут иметь непреходящее значение для будущих сравнений циклов подобного уровня.

\section{Заключение}

Таким образом, анализ собранных материалов подтверждает существенное увеличение разнообразия видового состава куликов на Байкале во второй половине XX и начале XXI в. по сравнению с предшествующим периодом. Основная причина этого - обширные (нередко охватывающие всю Монголию и значительную часть Китая) и продолжительные засухи в Центральной Азии. Это подтверждается и составом новых видов куликов, представленных исключительно южными видами, северные границы гнездовых ареалов которых находились вблизи южных границ России. Северные границы ареалов ряда многочисленных видов куликов продвинулись далеко на север (на 500 км и более) и достигли Центральноякутской низменности. Тем не менее большая часть новых, преимущественно южных, видов куликов регистрируется в Восточной Сибири только залетом, с регистрацией единичных случаев эпизодических гнездовий. Современные ареалы куликов имеют вид длинных шлейфов, идущих от их южных границ к оптимумам ареалов, расположенным далеко на севере, с благоприятными условиями обитания. Часто такие шлейфы имеют очаговый характер с более высокой плотностью гнездования в благоприятных местах. Выделение оптимумов их современных ареалов, отличающихся заметно более высокой плотностью гнездования, имеет большое значение для прогнозных характеристик будущих их изменений.

\section{Лuтература}

Ананин А. А. Общий обзор фауны птиц Северо-Восточного Прибайкалья (Баргузинский хребет) // Тр. гос. зап-ка «Байкало-Ленский». 2001. Вып. 2. C. $66-82$.

Афанасьев А. Н. Колебания гидрометеорологического режима на территории СССР. М.: Наука, 1967. 231 с.

Афанасьев М. А. Интересные встречи птиц в окрестностях с. Сунтар (Сунтарский улус, Республика Саха (Якутия) // Байкал. зоол. журн. 2018. № 1(22). C. 97-98.

Бадмаева Е. Н. Кулики степных озер Юго-Западного Забайкалья // Сибирская орнитология (специальная серия). 2006. Вып. 4. С. 18-33.

Байкал. Атлас. М.: Роскартография, 1993. 160 с. 
Ю. И. Мельников. Динамика фауны куликов котловины озера Байкал и ее связь с современными изменениями климата (конец XVIII — начало XXI в.)

Бережных Т. В., Марченко О. Ю., Абасов Н. В., Мордвинов В. И. Изменение летней циркуляции атмосферы над Восточной Азией и формирование длительных маловодных периодов в бассейне р. Селенги // География и природные ресурсы. 2012. № 3. С. 61-68.

Богородский Ю. В. Птицы Южного Предбайкалья. Иркутск: Изд-во ИГУ, 1989. $208 \mathrm{c}$.

Болд А., Доржиев Ц. З., Юмов Б. О., Цэвэнмядаг Н. Фауна птиц бассейна озера Байкал // Экология и фауна птиц Восточной Сибири. Улан-Удэ: Изд-во Бурят. гос. ун-та, 1991. С. 3-24.

Васильченко А.А. Птицы Хамар-Дабана. Новосибирск: Наука, 1987. 103 с.

Воробьев К.А. К орнитофауне оз. Байкал // Комис. по изучению оз. Байкал. Л.: Изд-во АН СССР, 1927. Т. 2. С. 55-62.

Воронин В. И., Хантемиров Р. М., Наурзбаев М. М. Сверхдлинные сибирские древесно-кольцевые хронологии - надежные архивы для палеоклиматических реконструкций // Развитие жизни в процессе абиотических изменений на Земле: материалы III науч.-практ. конф. (23-30 сентября 2014 г., п. Листвянка, Иркутская обл., Россия). Новосибирск: Изд-во ИГ им. В. Б. Сочавы, 2014. C. 409-415.

Гагина Т. Н. Птицы Восточной Сибири (список и распространение) // Труды госзаповедника «Баргузинский». 1961. Вып. 3. С. 99-123.

Гагина Т. Н. Кулики Восточной Сибири и их охрана // Природа, ее охрана и рациональное использование. Иркутск: Изд-во ИСХИ, 1974. С. 132-136.

Гагина Т. Н. Список птиц бассейна озера Байкал // Экология наземных позвоночных Восточной Сибири. Иркутск: Изд-во ИГУ, 1988. С. 85-123.

Гладков Н. А. Отряд кулики Limicolae или Charadriiformes // Птицы Советского Союза. М.: Советская наука, 1951. Т. 3. С. 3-372.

Гусев О. К. О гнездовании птиц на островах Чивыркуйского залива Байкала и оз. Ранготуя // Тр. гос. зап-ка «Баргузинский». 1960. Вып. 2. С. 155-174.

Дегтярев В. Г. Водно-болотные птицы в условиях криоаридной равнины. Новосибирск: Наука, 2007. 291 с.

Доржиев Ц. 3. Птицы Байкальской Сибири: систематический состав, характер пребывания и территориальное размещение // Байкал. зоол. журн., 2011. № 1(6). С. $30-62$.

Доржиев Ц. З., Елаев Э. Н. Фауна птиц бассейна озера Байкал: систематический и экологический анализ // Биоразнообразие Байкальской Сибири. Новосибирск: Наука, 1999. С. 274-287.

Доржиев Ц. 3., Бадмаева Е. Н. Неворобьиные птицы Non-Passeriformes Pecпублики Бурятия: аннотированный список // Природа Внутренней Азии - Nature of the Inner Asia. 2016. Вып. 1. C. 7-60.

Доржиев Ц. 3., Бадмаева, Е. Н., Цэвээнмядаг Н. Эколого-систематическая характеристика водно-болотных птиц бассейна озера Байкал // Природа Внутренней Азии - Nature of the Inner Asia. 2018. № 3(8). С. 51-83.

Дыбовский Б. И., Годлевский В. А. Предварительный отчет о фаунистических исследованиях на Байкале // Приложение к отчету Сиб. отдел. РГО. СПб., 1870. C. 167-204. 
Жеребцов Г. А., Коваленко В. А., Молодых С. И., Рубцова О. А. Закономерности климатических изменений в XX в. и основные физические процессы, ответственные за эти изменения // Изв. Иркутск. гос. ун-та. Сер. Науки о Земле. 2011. T. 4, № 1. C. 87-108.

Жеребцов Г. А., Коваленко В. А., Молодых С. И., Кириченко К. Е. Влияние солнечной активности на температуру тропосферы и поверхности океана // Изв. Иркутск. гос. ун-та. Сер. Науки о Земле. 2013. Т. 6, № 1. С. 61-79.

Журавлев В. Е., Подковыров В. А., Скрябин Н. Г., Тупицын И. И., Шинкаренко А. В. Краткий очерк фауны куликов дельты Селенги // Экология и фауна птиц Восточной Сибири. Улан-Удэ: Изд-во БНЦ СО РАН, 1991. С. 93-100.

Закс Л. Статистическое оценивание. М.: Статистика, 1976. 598 с.

Измайлов И. В. Птицы Витимского плоскогорья. Улан-Удэ: Бурят. кн. изд-во, 1967. 205 c.

Измайлов И. В., Боровицкая Г. К. Птицы Юго-Западного Забайкалья. Владимир: Изд-во Владимир. ГПИ, 1973. 315 с.

Кирилюк В. Е., Ткачук Т. Е., Кирилюк О. К. Влияние изменений климата на местообитания и биоту в Даурии // Проблемы адаптации к изменению климата в бассейнах рек Даурии: экологические и водохозяйственные аспекты. Чита: Экспресс, 2012. Вып. 5. С. 4-62.

Коблик Е. А., Редькин Я. А., Архипов В. Ю. Список птиц Российской Федерации. М.: Тов-во научн. изд. КМК, 2006. 256 с.

Кошеленко И. В. Засухи и борьба с ними: обзор. Обнинск: Изд-во ВНИИГМИ-МЦД, 1983. 56 с.

Кривенко В. Г. Водоплавающие птицы и их охрана. М.: Агропромиздат, 1991. $271 \mathrm{c}$.

Кривенко В. Г., Виноградов В. Г. Птицы водной среды и ритмы климата Северной Евразии. М.: Наука, 2008. 588 с.

Лаппо Е. Г., Томкович П. С., Сыроечковский Е. Е.-мл. Атлас ареалов гнездящихся куликов Российской Арктики. М., 2012. 448 с.

Латышева И. В., Лощенко К. А., Шахаева Е. В. Исследования динамики азиатского антициклона и холодных циркуляционных периодов на территории Иркутской области // Изв. Иркутск. гос. ун-та. Сер. Науки о Земле. 2011. Т. 4, № 2. C. $161-171$.

Леви К. Г., Задонина Н. В., Бердникова Н. Е., Воронин В. И., Глызин А. В., Язев С. А., Баасанджав Б., Нинжбадгар С., Балжинням Б., Буддо В. Ю. Современная геодинамика и гелиогеодинамика: 500-летняя хронология аномальных явлений в природе и социуме Сибири и Монголии. Иркутск: Изд-во ИГТУ, 2003. $83 \mathrm{c}$.

Леви К. Г., Воронин В. И., Мирошниченко А. И., Козырева Е. А., Александрова А. К. Гелиогеодинамика. Природные аспекты глобальных солнечных минимумов. Иркутск: Изд-во ИГУ, 2017. Т. 2, кн. 1. 547 с.

Липин С. И., Толчин В. А., Вайнштейн Б. Г., Сонин В. Д. К изучению куликов Братского водохранилища // Орнитология. М.: Изд-во МГУ, 1968. Вып. 9. C. 214-221.

Малеев В. Г., Попов В. В. Птицы лесостепей Верхнего Приангарья. Иркутск: НЦРВХ СО РАМН, 2007. 300 c. 
Ю. И. Мельников. Динамика фауны куликов котловины озера Байкал и ее связь с современными изменениями климата (конец XVIII — начало XXI в.)

Мельников Ю.И. О некоторых адаптациях прибрежных птиц // Экология. 1982. № 2. С. 64-70.

Мельников Ю. И. Численность и распределение редких и малоизученных птиц дельты р. Селенги // Орнитология. М.: Изд-во МГУ, 1984. Вып. 19. С. 58-63.

Мельников Ю. И. Американский бекасовидный веретенник (Limnodromus scolopaceus): западная граница ареала и внутриазиатский пролетный путь // Труды госзаповедника «Байкало-Ленский». 1998. Вып. 1. С. 75-77.

Мельников Ю. И. Пути миграций и территориальные связи околоводных и водоплавающих птиц Предбайкалья // Инвентаризация, мониторинг и охрана ключевых орнитологических территорий России. М.: Изд-во СОПР, 1999. C. $143-147$.

Мельников Ю. И. Новые материалы о фауне птиц дельты реки Селенги (Южный Байкал) // Рус. орнитол. журн. Экспресс-вып. 2000. № 102. С. 3-19.

Мельников Ю. И. Азиатский бекасовидный веретенник: динамика численности и ее особенности на северной границе ареала // Орнитологические исследования в Сибири и Монголии. Улан-Удэ: Изд-во Бурят. гос. ун-та, 2003. Вып. 3. C. $160-181$.

Мельников Ю. И. Экстремальные засухи и их влияние на динамику гнездовых ареалов куликов Прибайкалья // Кулики Восточной Европы и Северной Азии: изучение и охрана. Екатеринбург: Изд-во УралГУ, 2004а. С. 132-137.

Мельников Ю. И. Пути миграций и динамика ареала азиатского бекасовидного веретенника Limnodromus semipalmatus на юге Западно-Сибирской равнины // Рус. орнитол. журн. Экспресс-вып. 2004б. № 262. С. 471-495.

Мельников Ю. И. Циклические изменения климата и динамика ареалов птиц на юге Восточной Сибири // Орнитогеография Палеарктики: современные проблемы и перспективы. Махачкала: Изд-во ДГПУ, 2009. С. 47-69.

Мельников Ю. И. Структура ареала и экология азиатского бекасовидного веретенника Limnodromus semipalmatus (Blyth, 1848). Иркутск: НЦРВХ СО PAMH, 2010. $284 \mathrm{c}$.

Мельников Ю. И. Пространственная структура лугово-болотных видов куликов в гнездовой период: избирательность микростаций и ее причины (на примере устья р. Иркут) // Изв. Иркутск. гос. ун-та. Сер. Биология. Экология. 2011а. T. 4(1). C. 33-46.

Мельников Ю. И. Фауна куликов Восточной Сибири: общие тенденции изменения на протяжении XX столетия // Кулики Северной Евразии: экология, миграции и охрана. Ростов н/Д: Изд-во ЮНЦ РАН, 2011б. С. 37-57.

Мельников Ю. И. Птицы Ново-Ленинских (Иннокентьевских) болот города Иркутска во второй половине XX столетия: видовая структура, обилие и фенология основных жизненных циклов // Байкал. зоол. журн. 2011 в. № 2(7). С. 30-68.

Мельников Ю. И. Динамика плотности населения, численности и распределения куликов по местообитаниям в 11-летнем внутривековом климатическом цикле 1973-1982 годов в дельте Селенги // Рус. орнитол. журн. Экспресс-вып. 2013. T. 22, № 890. С. $1625-1678$.

Мельников Ю. И. Современные изменения ареалов и плотности населения массовых видов куликов Восточной Сибири // Кулики в изменяющейся среде Северной Евразии. М.: Тезаурус, 2014. С. 100-103. 
Мельников Ю. И. Современные климатические тенденции в Центральной Азии и их влияние на динамику фауны птиц Восточной Сибири // Экосистемы Центральной Азии в современных условиях социально-экономического развития. Улан-Батор, 2015. Т. 1. С. 333-337.

Мельников Ю. И. Современная фауна птиц котловины озера Байкал и особенности ее формирования // Изв. Иркутск. гос. ун-та. Сер. Биология. Экология. 2016a. T. 16. С. 62-83.

Мельников Ю. И. Распространение и экология турухтана (Philomachus pugnax Linnaeus, 1758) на южной границе гнездового ареала в Восточной Сибири // Вопросы экологии, миграции и охрана куликов Северной Евразии. Иваново: Изд-во Иван. ГУ, 2016б. С. 241-249.

Мельников Ю. И. Новые виды птиц котловины озера Байкал (вторая половина XX - начало XXI столетия) // Природа Внутренней Азии - Nature of the Inner Asia. 2017. № 3(4). C. 38-63.

Мельников Ю. И. Новые виды птиц котловины озера Байкал: анализ видовой и экологической структуры // Изв. Иркутск. гос. ун-та. Сер. Биология. Экология. 2018. Т. 24. С. 25-48.

Мельников Ю. И., Гагина-Скалон Т. Н. Птицы озера Байкал (с конца XIX по начало XXI столетия): видовой состав, распределение и характер пребывания // Бюл. МОИП. Отд. биол. 2016. Вып. 2. С. 13-32.

Мельников Ю. И., Трошкова Т. Л. Видовой состав, плотность населения, численность и распределение куликов Иркутского водохранилища в гнездовой период // Вопросы экологии, миграции и охраны куликов Северной Евразии. Иваново: Изд-во ИванГУ, 2016. С. 249-257.

Мухина Л. И., Преображенский В. С., Томилов Г. М., Фадеева Н. В. Природное районирование // Предбайкалье и Забайкалье. Природные условия и естественные ресурсы СССР. М.: Наука, 1965. С. 323-336.

Новороцкий П. В. Изменение климата в бассейне Амура // Влияние изменения климата на экосистемы бассейна реки Амур. M.: WWF-Russia, 2006. C. 22-41.

Обязов В. А. Изменение климата и гидрологического режима рек и озер в Даурском экорегионе // Проблемы адаптации к изменению климата в бассейнах рек Даурии: экологические и водохозяйственные аспекты (Труды гос. заповедника «Даурский», вып. 5). Чита: Экспресс, 2012. С. 24-45.

Оловянникова Н.М. Авифауна Байкало-Ленского заповедника // Тр. госзаповедника «Байкало-Ленский». 2006. Вып. 4. С. 183-197.

Попов В. В. Птицы (Aves) // Аннотированный список фауны озера Байкал и его водосборного бассейна. Новосибирск: Наука, 2004. Т. 1, кн. 2. Озеро Байкал. C. $1062-1198$.

Попов В. В. Кадастр позвоночных животных Иркутской области, не относящихся к объектам охоты. Иркутск: НЦРВХ СО РАМН, 2009. 70 с.

Попов В. В., Матвеев А. Н. Охрана позвоночных животных в Байкальском регионе. Иркутск: НЦРВХ СО РАМН, 2006. 110 с.

Преловский В. А. Динамика фауны и населения куликов озера Байкал // Кулики Северной Евразии: экология, миграции и охрана. Ростов н/Д: Изд-во ЮНЦ PAH, 2011. C. 77-93. 
Ю. И. Мельников. Динамика фауны куликов котловины озера Байкал и ее связь с современными изменениями климата (конец XVIII — начало XXI в.)

Пыжьянов С. В. Список птиц побережья Малого Моря и прилегающих территорий // Тр. Прибайк. нац. парка. 2007. Вып. 2. С. 218-229.

Романов А. А. Авифауна гор Азиатской субарктики: закономерности формирования и динамики. М., 2013. 358 с.

Рябицев В. К. Птицы Сибири: справочник-определитель. М.; Екатеринбург: Кабинетный ученый, 2014. Т. 2. 452 с.

Рябцев В. В. Динамика орнитофауны Прибайкальского национального парка на рубеже XX-XXI веков // Тр. Прибайк. нац. парка. 2007. Вып. 2. С. 230-254.

Сафронов Н. Н. Особенности весенней миграции куликов в долине реки Верхней Ангары // Первая конф. молодых ученых. Иркутск: Изд-во ИГУ, 1983. C. 33-34.

Сафронов Н. Н. О гнездовании азиатского бекасовидного веретенника на Северном Байкале // Вторая конф. молодых ученых. Иркутск: Изд-во ИГУ, 1984. Ч. 2. С. 35.

Скрябин Н. Г. К орнитофауне Прибайкалья // Орнитология. М.: Изд-во МГУ, 1967. Вып. 8. С. 386-387.

Скрябин Н. Г. Водоплавающие птицы Байкала. Иркутск: Вост.-Сиб. кн. изд-во, 1975. 244 с.

Словцов И. Я. Позвоночные Тюменского округа и их распространение в Тобольской губернии. М., 1892.78 с.

Сумъяа Д., Скрябин Н. Г. Птицы Прихубсугулья, МНР. Иркутск: Изд-во ИГУ, 1989. 200 с.

Сыроечковский Е. Е.-ст. Изменение ареалов птиц в Средней Сибири в результате потепления климата и воздействия человека // Орнитология. М.: Изд-во МГУ, 1960. Вып. 3. С. 212-218.

Тарасов В. В., Коршиков Л. В. К вопросу о гнездовании тундровых видов куликов в Оренбургских степях в ХIX веке // Зоол. журн. 2018. Т. 97, № 12. C. $1513-1524$.

Тачановский В. К. Критический обзор орнитологической фауны Восточной Сибири // Труды 5-го съезда русских естествоиспытателей и врачей в Варшаве. Отд. Зоологии. Варшава, 1887. Т. 3. С. 284-386.

Ткаченко Е. Э., Обязов В. А. Изменение уровня Торейских озер и гнездящиеся колониальные околоводные птицы // Наземные позвоночные Даурии: Труды госзаповедника «Даурский». 2003. Вып. 3. С. 44-59.

Толчин В. А. Характер пролета куликов на северном Байкале и его связь с температурным ходом весны // Материалы всесоюзн. конф. по миграциям птиц. М.: Наука, 1975. Ч. 1. С. 144-145.

Толчин В. А. Турухтан (Philomachus pugnax) в Прибайкалье // Зоол. журн. 1976а. Т. 55, вып. 2. С. 308-311.

Толчин В. А. Распространение и экология поручейника (Tringa stagnatilis Bechst.) в Средней Сибири // Научн. докл. высш. школы. Биол. науки. 1976б. № 5. C. $42-48$.

Толчин В. А. Распространение и экология чибиса (Vanellus vanellus) в Восточной Сибири // Фауна и экология птиц Восточной Сибири. Иркутск: Изд-во ИГУ, 1984. С. 111-131. 
Толчин В. А., Мельников Ю. И. О гнездовании и экологии большого веретенника (Limosa limosa melanuroides L.) в Восточной Сибири // Научн. докл. высш. школы. Биол. науки. 1974. № 11. С. 27-30.

Толчин В. А., Мельников Ю. И. О гнездовании азиатского бекасовидного веретенника (Limnodromus semipalmatus Blyth.) в Восточной Сибири // Вестн. зоологии. 1977. № 3. С. 16-19.

Толчин В. А., Заступов В. П., Сонин В. Д. Материалы к познанию куликов Байкала // Орнитология. М.: Изд-во МГУ, 1977. Вып. 13. С. 40-48.

Третьяков А. В. К орнитофауне острова Ольхон по наблюдениям экспедиции 1933 года // Тр. Вост.-Сиб. гос. ун-та. 1934. Т. 2. С. 118-133.

Туров С. С. Материалы по фауне птиц Баргузинского края // Труды проф. и препод. Иркутск. гос. ун-та. 1923. Т. 4. С. 132-169.

Фефелов И. В. Ошибочное включение двух видов в список птиц Байкальского региона // Рус. орнитол. журн. Экспресс-вып. 2015. Т. 24, № 1096. С. 214 215.

Фефелов И. В., Тупицын И. И., Подковыров В. А., Журавлев В. Е. Птицы дельты Селенги: фаунистическая сводка. Иркутск: Вост.-Сиб. изд. комп., 2001. $320 \mathrm{c}$.

Фомин В. Е., Болд А. Каталог птиц Монгольской Народной Республики. М.: Наука, 1991. 125 с.

Швецов Ю. Г., Швецова И. В. Птицы дельты Селенги // Изв. ИСХИ. 1967. Вып. 25. С. 224-231.

Шимараев М. Н., Старыгина Л. Н. Зональная циркуляция атмосферы, климат и гидрологические процессы на Байкале (1968-2007) // География и природные ресурсы. 2010. № 3. С. 62-68.

Шимараев М. Н., Куимова Л. Н., Синюкович В. Н. Тенденции изменения абиотических условий в Байкале в современный период // Развитие жизни в процессе абиотических изменений на Земле: докл. науч.-практ. конф. (18-20 марта 2008 г., пос. Листвянка, Иркутск. обл., Россия). Новосибирск: Изд-во СО РАН, 2008. C. 311-318.

Шнитников А. В. Изменчивость общей увлажненности материков северного полушария // Зап. Географ. общества СССР. М.; Л.: Изд-во АН СССР, 1957. Т. 16. $336 \mathrm{c}$.

Cheng S. S. M. Dry spelles during mid-summer over South China // Techn. Nat. Roy / Observ. Hong-Kong, 1978. № 44. P. 35.

Colston P. R. Occurrence of the Western Sandpiper Calidris mauri at Lake Baikal, U.S.S.R. // Bull. Brit. Ornithol. Club, 1975. Vol. 95. P. 141-142.

Georgi J. G. Bemerkungen einer Reise im Russischen Reich im Jahre 1772. StPetersburg, 1775. Vol. 2. 920 s.

Maak R. An expedition to Amur, made on behalf of the Siberian Department of the Russian Geographic Society in 1855. St-Petersburg, 1859.

MacKinnon J., Phillipps K., Fen-qi He. A field guide to the Birds of China. NewYork, 2000. $586 \mathrm{p}$.

Mel'nikov Yu. I. Wetland ecosystems dynamics and their protection in territory of the Central Asia and adjacent regions // Ecosystems of Mongolia and frontier areas of 
Ю. И. Мельников. Динамика фауны куликов котловины озера Байкал и ее связь с современными изменениями климата (конец XVIII — начало XXI в.)

adjacent countries: natural resources biodiversity and ecological prospects. Ulanbaatar: Bembi San Publ., 2005. P. 296-297.

Mel'nikov Yu. I. Modern Climate and Dynamics of Bird Fauna lake Baikal (Eastern Siberia) // Academic science - problems and achievements X: Proc. Conf. (24-25 October 2016, Sc, USA). North Charleston: Create Space Publ., 2016. Vol. 2. P. 1-13.

Mlikovsky J. Waterbirds of Lake Baikal, eastern Siberia, Russia // Forktail, 2009. Vol 25. P. 13-70.

Ofori-Sarpong E. The 1975-1977 drought in China. Hydrometeorological aspects // Bull. Inst. Fondam. afr. fondam. afr. Noise, 1980. Vol. 42. № 4. P. 649-661.

Fefelov I., Tupitsyn I. Waders of the Selenga delta. Lake Baikal, eastern Siberia // Wader Study Group Bull., 2004. Vol. 104. P. 66-78.

Radde G. Reisenim Süden von Ost-Sibirien in den Jahren 1855-1859. Die Festlands-ornis des südöstlichen Sibiriens. St-Petersburg, 1863. Vol. 2. S. 11-392.

Taczanowski L. Faune ornithologique de la Siberie orientale // Mem. de 1'Acad. Sci. St.-Petersburge, 1893. Vol. 39. № 7.1278 p.

Stegmann B. Die Vogel Sud-Ost Transbaikaliens // Ежегодн. Зоол. музея АН CCCP, 1929. Vol. 29. S. 366-390.

Stegmann B. Die Vogel des nordlichen Baikal // J. Ornithologie, 1936. Vol. 84(58). S. 58-139.

Yelayev E. N. Long-billed Dowitcher (Limnodromus scolopaceus Say, 1823) in the Asian part of Russia: area and chronology of the meetings in the Baikal Siberia // Nature of the Inner Asia. 2017. № 4(5). P. 73-75. 


\title{
DYNAMICS OF THE FAUNA OF WARDERS IN THE LAKE BAIKAL BASIN AND ITS CORRELATION WITH CURRENT CLIMATOLOGICAL CHANGES (THE END OF THE $18^{\text {th }}-$ THE BEGINNING OF THE $21^{\text {st }}$ CENTURIES)
}

\author{
Yu. I. Melnikov \\ Yuriy I. Melnikov \\ Cand. Sci. (Biol.), \\ Baikal Museum of Irkutsk Scientific Center, \\ 1 Akademicheskaya St., Listvyanka 664520, Irkutsk Oblast, Russia \\ E-mail: yumel48@mail.ru
}

The article discusses the dynamics of the fauna of waders in the Lake Baikal basin depending on climatological changes (warming) over a very long period of observations (end of the $18^{\text {th }}$ - the beginning of the $21^{\text {st }}$ centuries). Until the middle of the $20^{\text {th }}$ century Eastern Siberia was in a humid and cold period of a centuries-old climate cycle, related to the late Glacial, which lasted about 2000 years. In this regard, the species composition of waders at that time was very poor - 45 species, although some of them reached a very high abundance. From the second half of the $20^{\text {th }}$ century due to the pronounced climate warming, the species composition of warders in Lake Baikal basin significantly increased (from 45 to 57 species), in total in Eastern Siberia there are 63 species. The sharp increase in the species composition and the number of birds of this group are a consequence of the relocation of a number of typically southern species of waders to the north. It has been proven that mass relocation of these birds to the north is initiated by large, often catastrophic droughts in Central Asia, accompanied by long low-water periods. Birds of wet and marshy meadows which area sharply decreases as a result of a very strong drying out are relocated first. So, the beginning of the second half of the $20^{\text {th }}$ century was characterized by mass relocations of meadow-marsh wader species that penetrated to the Central Yakut Plain (northern lapwing, marsh sandpiper, common greenshank, wood sandpiper). At the end of the $20^{\text {th }}$ century due to a very strong drying of wet meadows in the south of Eastern Siberia, there were shifts of the optimums of ranges far to the north - the most common species of waders of this group, such as common snipes, pintail snipes, forest snipes, and ruffs, moved $500 \mathrm{~km}$ or more to the north. At that time the abundance of the most numerous species of waders which were typical for wet-cold period of the Late Glacial climate $\left(19^{\text {th }}\right.$ - the first half of the $20^{\text {th }}$ centuries) had been sharply reduced. The southern borders of their ranges remained almost unchanged, but the density of the bird population decreased by 2-3 times or more. Only separate breeding pairs of some species (common greenshank, wood sandpiper) are found in the places, where earlier there was high abundance of them. At the beginning of the $21^{\text {st }}$ century the relocation concerned desert, steppe and alpine species of waders. The green sandpiper - one of the most widespread species of the previous period leaves even the north of Eastern Siberia. The species composition increases mainly due to vagrant and single-nesting southern species of waders, the northern limits of their ranges were previously located near the borders of Russia. It should be noted that we are talking about a group of birds that naturalize in wetland ecosystems, which are intrazonal habitats of almost all natural zones and mountain belts, and it facilitates extensive movements of such birds.

Keywords: Lake Baikal; climate; wader fauna; species composition; number, range dynamics. 